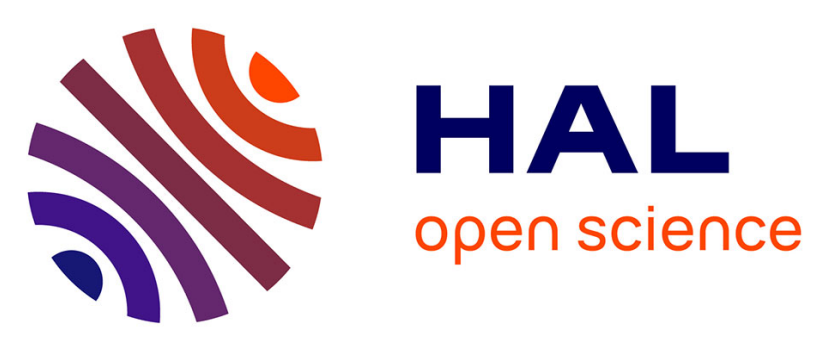

\title{
Habitat characteristics and species interference influence space use and nest-site occupancy: implications for social variation in two sister species
}

Claire Marie Soleil Dufour, Neville Pillay, Nico Avenant, Johan Watson, Etienne Loire, Guila Ganem

\section{To cite this version:}

Claire Marie Soleil Dufour, Neville Pillay, Nico Avenant, Johan Watson, Etienne Loire, et al.. Habitat characteristics and species interference influence space use and nest-site occupancy: implications for social variation in two sister species. Oikos, In press, 10.1111/oik.05357 . hal-01912223

\section{HAL Id: hal-01912223 \\ https://hal.science/hal-01912223}

Submitted on 19 Nov 2018

HAL is a multi-disciplinary open access archive for the deposit and dissemination of scientific research documents, whether they are published or not. The documents may come from teaching and research institutions in France or abroad, or from public or private research centers.
L'archive ouverte pluridisciplinaire HAL, est destinée au dépôt et à la diffusion de documents scientifiques de niveau recherche, publiés ou non, émanant des établissements d'enseignement et de recherche français ou étrangers, des laboratoires publics ou privés. 
Article scientifique OIKOS 2018

Langue: English

DOI: 10.1111/oik.05357

\section{Habitat characteristics and species interference influence space use and nest-site occupancy: implications for social variation in two sister species}

\section{(1)}

Claire M. S. Dufour ${ }^{1,2,+, *}$, Neville Pillay ${ }^{2}$, Nico Avenant $^{3}$, Johan Watson $^{4}$, Etienne Loire $^{5}$, Guila

(1)

$$
\text { Ganem }^{1,2,+}
$$

${ }^{1}$ ISEM, CNRS, University of Montpellier, IRD, EPHE, Montpellier, France

* Current address: Museum of Comparative Zoology, Department of Organismic and Evolutionary

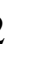
Biology, Harvard University, Cambridge, MA, U.S.A.

${ }^{2}$ School of Animal, Plant and Environmental Science, University of the Witwatersrand, P/Bag 3, 2050

(1)

$$
\text { Wits, South Africa }
$$

${ }^{3}$ Department of Mammalogy, National Museum, and Centre for Environmental Management, University of the Free State, Bloemfontein, South Africa

${ }^{4}$ Department of Economic Development, Tourism and Environmental Affairs, Biodiversity Research, 8

$$
\text { P/Bag X20801 } 9300 \text { Bloemfontein, South Africa }
$$

${ }^{5}$ Centre de Coopération Internationale en Recherche Agronomique pour le Développement (CIRAD), UMR, CMAEE, C2B, Montpellier (France)

$$
\text { + Corresponding authors }
$$

clairems.dufour@gmail.com

$$
\text { guila.ganem@umontpellier.fr }
$$

\footnotetext{
ORCID Dufour Claire: 000000032270 938X
}

ORCID Ganem Guila: 0000-0002-5244-4979 
Nest-site selection is an important component of species socio-ecology, being a crucial factor in establishment of group living. Consequently, nest-site characteristics together with space-use proxies may reveal the social organization of species, which is critical when direct observation of social interactions is hindered in nature. Importantly, nest-site choice is expected to be under strong selective pressures and the object of intra- and inter-specific competition. Although the bulk of research on sociality focuses on its ecological drivers, our study introduces interspecific competition as a potential factor that could influence social evolution. We investigated the influence of habitat and interspecific competition on the social organization of two sister species of the African four striped mouse (Rhabdomys dilectus dilectus and Rhabdomys bechuanae) in a similar macroenvironment. These species diverged in allopatry and occupy distinct environmental niches. We radiotracked 140 adults to identify their nest-sites, determine nest characteristics and record groups that shared nest-sites. Group cohesion was estimated from nest-site fidelity, group association strength, and home range overlap within versus between group members. We compared the two species in sympatry versus parapatry to determine the impact of species interference on sociality. In parapatry, the two species selected distinct nest-site types, interpreted as different antipredator strategies: $R$. bechuanae selected fewer, spaced, less concealed nest-sites whereas $R . d$. dilectus selected clumped and less visible nest-sites. Rhabdomys bechuanae also showed more cohesive and stable social groups than $R$. $d$. dilectus. In sympatry, compared to $R$. bechuanae, $R$. d. dilectus occupied similar nest-sites, however slightly more exposed and clumped, and displayed similar nest-site fidelity and group association strength. We conclude that although habitat selection may be an important driver of social divergence in Rhabdomys, species interference, by limiting $R$. $d$. dilectus movements and forcing nest-site sharing may induce new ecological pressures that could influence its social evolution.

Key words: habitat selection, home range overlap, interspecific competition, nest-site sharing, radiotracking, Rhabdomys, secondary contact, social groups 